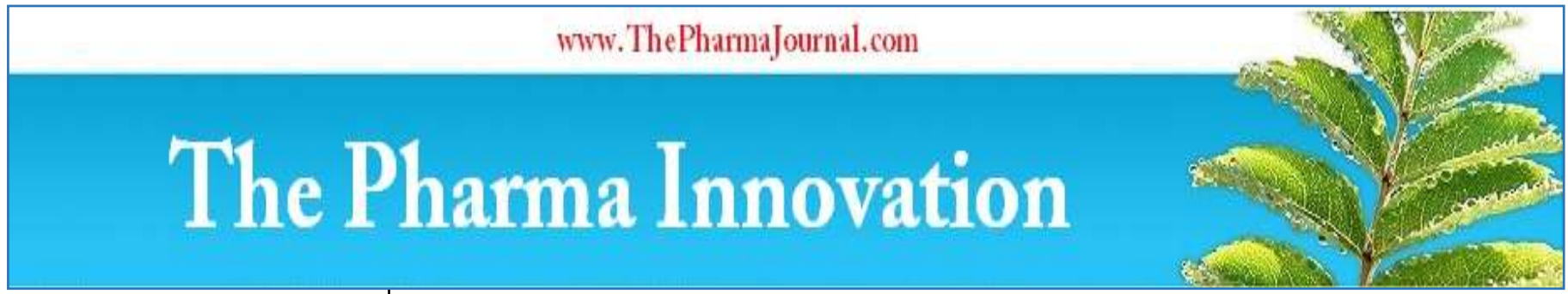

ISSN (E): 2277- 7695

ISSN (P): 2349-8242

NAAS Rating: 5.23

TPI 2021; SP-10(3): 215-219

(C) 2021 TPI

www.thepharmajournal.com

Received: 07-01-2021

Accepted: 14-02-2021

\section{Karthik D}

PhD Scholar, SRS of ICAR, NDRI, Bengaluru, Karnataka, India

Devi MCA

Senior Scientist, SRS of ICAR

NDRI, Bengaluru, Karnataka, India

\section{Subash S}

Scientist, SRS of ICAR, NDRI,

Bengaluru, Karnataka, India

Dixit PK

Principal Scientist, SRS of ICAR, NDRI, Bengaluru, Karnataka, India

\section{Ramesha KP}

Principal Scientist, SRS of ICAR, NDRI, Bengaluru,

Karnataka, India

Jayaraj Rao K

Principal Scientist, SRS of ICAR, NDRI, Bengaluru,

Karnataka, India

Sivaram M

Principal Scientist, SRS of ICAR, NDRI, Bengaluru, Karnataka, India

Corresponding Author:

Karthik D

PhD Scholar, SRS of ICAR, NDRI, Bengaluru, Karnataka, India

\section{Profile characteristics of youth in dairying in Telangana state, India}

\author{
Karthik D, Devi MCA, Subash S, Dixit PK, Ramesha KP, Jayaraj Rao K \\ and Sivaram $M$
}

DOI: https://doi.org/10.22271/tpi.2021.v10.i3Sd.5898

\section{Abstract}

The present study is focused to study profile characteristics of Youth in Dairying Telangana State. A total of 220 respondents were selected across the state and interviewed. Most of the respondents belonged to the age group of 30-35 years, male, possessed high school level of education, belonged to nuclear family with small family size up to 5 members, were small farmers with medium livestock possession and high level of dairy farming experience, medium level of milk production and annual income, low level of training received, medium level of marketing behaviour, low level of participation in extension activities, medium level of information seeking behaviour and knowledge on improved dairy farming practices.

Keywords: Youth, dairy entrepreneurship, market behaviour, knowledge, information seeking behavior

\section{Introduction}

The increasing number of unemployed youth is one of the daunting problems faced by both developed and developing countries. India has the largest youth population in the world which is estimated to be 550 million (Government of India, 2011b) ${ }^{[3]}$. For rural youth in particular, new business creation in the agriculture sector can present an important and viable opportunity to earn a decent living. World Bank (2007) ${ }^{[16]}$ report states that the youth's attitude towards farming is mostly negative asrural youth are already engaged in informal agriculture in some way, they may not see it as an attractive or viable career option given such obstacles as geographic isolation, unfriendly land use policies, poor infrastructure, high transport costs, and unavailable agricultural inputs. The biggest challenge of India in coming years will be to retain youth in agriculture (Swaminathan, 2011) ${ }^{[13]}$. The reason that can be cited is the pull factors created in the urban areas and push factors in rural areas. Youth have greater propensity and willingness to adopt new ideas and hence youth can be potential target for entrepreneurship development in dairying. With the right investments to support entrepreneurs in agriculture, profitable careers could await India's young population.

Dairying is one of most promising avenue for the Youth in the country as there is rise in demand of milk and milk products globally. Youth of the country needs to focus their attention in dairy sector to manage natural resources in a sustainable manner in order to meet growing milk demand and upgrade milk processing using innovative technologies so that it will increase acceptance of Indian dairy products in the global market. In this context the present study is focused to study profile characteristics of youth in dairying. The study focuses to identify the socio-economic conditions of youth in dairying which will help the policy makers in formulating development programmes for encouraging youth in dairying.

\section{Materials and methods}

The respondents selected for the study were young dairy farmers and were selected based on the criteria that they should involve selling of milk. An exhaustive list of young dairy farmers was obtained from concerned authorities in each mandal and 20 respondents from each mandal was selected randomly. The sampling procedure followed was multi-stage stratified sampling scheme. A structured interview schedule was developed for the study and data was collected through personal interview method. After collection of data the data was to frequencies and percentages and used to know the distribution of the respondents according to selected variables. 


\section{Results and discussion Socio-personal variables 1. Age}

From Table 4.1, it could be observed that, less than fifty per cent $(47.27 \%)$ of the respondents belonged to category-III of age group (30-35 years), followed by category-II of age group (39.09\%) and category-I of age group (13.64\%) age group. This might be due to the youth during age group of category-I and category-II being engaged in other sectors rather than agriculture and allied sectors. The results are in accordance with Gwary et al., (2011) ${ }^{[4]}$ where majority of youth fell under age group of 27-32 years.

\section{Gender}

Table 4.1 indicates that majority of the respondents $(75.45 \%)$ were male and 24.55 percent of respondents were female dairy entrepreneurs. The reason may be that men are the heads of the house and are supported by women counterparts at home, whereas women involved in dairying included women from Women Dairy Cooperative Societies (WDCS) and the male counterparts away from the families, migrated to urban areas for employment or separated or widows. The results are in accordance to results of Prosper et al., (2015) [11] and Mbah et al., (2016) ${ }^{[6]}$, where majority of the respondents in the study area were men.

\section{Education}

As indicated in Table 4.1 it could be inferred thata significant per cent $(45.91 \%)$ of respondents possessed high school education, followed by secondary education (16.82\%), intermediate/diploma (15.45\%), primary education $(8.64 \%)$, graduation and above $(7.73 \%)$ and illiterates $(5.45 \%)$. The reason might be due to the educational facilities at village was up to high school level of education. Dropouts after middle school and illiterates observed might be due to poor socioeconomic condition, to support their family, help their parents in agriculture and dairying. The research findings are in concurrence with that of Laishram (2012) [5], where majority youth in dairy farming received high school education.

\section{Family type}

It is clear from Table 4.1 that majority $(62.73 \%)$ of respondents belonged to nuclear family and 37.27 per cent of respondents belonged to joint family. The possible reasons could bein nuclear families the parents become more close to children and get enough time to spend with them, financial problem will be less prominent and money can be saved for future financial crisis which was felt by the respondents. The results are in conformity with the results of Porchezhiyan (2013) ${ }^{[10]}$ where almost two-thirds of families were nuclear families.

\section{Family size}

A perusal of Table 4.1 indicates majority $(62.73 \%)$ of the respondents had family size upto five members followed by 24.55 per cent medium (6 to 7 members) and 12.73 per cent high ( 7 and above) respectively. The probable reason could be due to the prominence of nuclear families in the study. The results were in accordance to Laishram (2012) ${ }^{[5]}$ where majority of youth had medium family size.

\section{Dairy farming experience}

Observations from Table 4.1indicate that, considerable majority $(58.64 \%)$ of the respondents had had high dairy farming experience followed by medium $(30.91 \%)$ and low $(10.45 \%)$ respectively. The reason for having high dairy farming experience is the youth are involved in dairy farming by a tradition of family occupation which has provided the respondents to acquire rich knowledge and dairying as an occupation along with the agriculture. The results are in confirmity to Pisure et al., (2014) and Mbah et al., (2016) ${ }^{[6],}$ where majority of dairy farmers had high dairy farming experience.

Table 1: Distribution of respondents according to socio-personal variables, $(n=220)$

\begin{tabular}{|c|c|c|c|c|}
\hline S. No & Variables & Category & Frequency & Per cent \\
\hline \multirow{3}{*}{1} & \multirow{3}{*}{ Age (Years) } & Category-I (18-23 years) & 30 & 13.64 \\
\hline & & Category-II (24-29 years) & 86 & 39.09 \\
\hline & & Category-III (30-35 years) & 104 & 47.27 \\
\hline \multirow{2}{*}{2} & \multirow{2}{*}{ Gender } & Male & 166 & 75.45 \\
\hline & & Female & 54 & 24.55 \\
\hline \multirow{6}{*}{3} & \multirow{6}{*}{ Education } & Illiterate & 12 & 5.45 \\
\hline & & Primary Education & 19 & 8.64 \\
\hline & & Secondary Education & 37 & 16.82 \\
\hline & & High school & 101 & 45.91 \\
\hline & & Intermediate/Diploma & 34 & 15.45 \\
\hline & & Graduation and above & 17 & 7.73 \\
\hline \multirow{2}{*}{4} & \multirow{2}{*}{ Family type } & Nuclear family & 138 & 62.73 \\
\hline & & Joint family & 82 & 37.27 \\
\hline \multirow{3}{*}{5} & \multirow{3}{*}{ Family size } & Small (upto 5 members) & 138 & 62.73 \\
\hline & & Medium (6 to 7 members) & 54 & 24.54 \\
\hline & & Large (more than 7 members) & 28 & 12.73 \\
\hline \multirow{3}{*}{6} & \multirow{3}{*}{ Dairy farming experience (in years) } & Low (1 to 6 years) & 23 & 10.45 \\
\hline & & Medium ( 7 to 13 years) & 68 & 30.91 \\
\hline & & High (14 to 20 years) & 129 & 58.64 \\
\hline & \multirow{3}{*}{ Social participation } & No participation & 46 & 20.91 \\
\hline \multirow[t]{2}{*}{7} & & Participation & 147 & 66.82 \\
\hline & & High participation & 27 & 12.27 \\
\hline \multirow{3}{*}{8} & \multirow{3}{*}{ Training received } & Low $(<3.12)$ & 113 & 51.36 \\
\hline & & Medium (3.12 to 6.34) & 83 & 37.73 \\
\hline & & High $(>6.34)$ & 24 & 10.91 \\
\hline
\end{tabular}




\section{Social participation}

As indicated from Table 4.1 majortity $(66.82 \%)$ of the respondents had medium level social participation, followed by low (20.91\%) and high level of participation $(12.27 \%)$ respectively. The reason might be that various agencies and rural development organizations encourage farmers for membership to facilitate access to information, input, credit and market which are critical to farmers. The finding are in similarity with the findings of Kumar (2008). But the findings of Mbah et al., (2016) ${ }^{[6]}$ revealed that majority (87.50\%) of rural youth did not have membership in any formal organizations.

\section{Training received}

Findings from Table 4.1 suggests that, more than fifty per cent $(51.36 \%)$ of the respondents possessed low level of training exposure, followed by medium $(37.73 \%)$ and high $(10.91 \%)$. As the farmers have to work in the field they are time availability, awareness and distance of training institutes and preference of respondents. The respondents generally attended trainings organized by the cooperative society mostly about importance of quality of milk might be the reason for low training exposure. The results are contrary to the findings of Avadh (2011) ${ }^{[1]}$ and Gaikwad (2010) ${ }^{[2]}$ where majority of respondents received medium level of training.

\section{Socio-economic Variables \\ 1. Land holding}

It is striking from Table 4.2 a considerable per cent $(46.82 \%)$ of the respondents were small farmers, followed by 33.64 per cent marginal $(33.64 \%), 11.82$ per cent medium $(11.82 \%)$ and large farmers $(7.72 \%)$ respectively. The reason for the findings majority of respondents might be that small and marginal farmers the average size of holding of majority of the state land holding fragmented over years. The findings are in confirmation to the results of Uddin et al., (2008) ${ }^{[14]}$ where majority of farmers were small farmers.

\section{Livestock possession}

It could be seen from Table 4.2 it can be observed that more than fifty per cent $(55.46 \%)$ of the respondents had medium livestock possession followed by low $(27.27 \%)$ and high $(17.27 \%)$ respectively. The reason for medium livestock possession as majority were small and marginal farmers and livestock is subsidiary activity which provides additional income to the farmers and also resilience during the time of unfavourable conditions. It is quite encouraging that average livestock possession was five animals where dairying perceived by the youth as an assured income generating activity. The results are in conformity with the results of Laishram (2012) ${ }^{[5]}$ and Pisure et al., (2014).

Table 2: Distribution of respondents according to socio-economic characteristics, $(n=220)$

\begin{tabular}{|c|c|c|c|c|}
\hline S. No & Variables & Category & Frequency & Per cent \\
\hline \multirow{4}{*}{1} & \multirow{4}{*}{ Land holding (in hectares) } & Marginal farmers (upto 1 hectare) & 74 & 33.64 \\
\hline & & Small farmers (1 to 2 hectares) & 103 & 46.82 \\
\hline & & Medium farmers ( 2 to 5 hectares) & 26 & 11.82 \\
\hline & & Large ( $>5$ hectares) & 18 & 7.72 \\
\hline \multirow{4}{*}{2} & \multirow{4}{*}{ Livestock Possession } & Low (<3 animals) & 60 & 27.27 \\
\hline & & Medium (4 to 8 animals) & 122 & 55.46 \\
\hline & & High (> 9 animals) & 38 & 17.27 \\
\hline & & Average herd size & \multicolumn{2}{|c|}{5} \\
\hline \multirow{4}{*}{3} & \multirow{4}{*}{ Milk production (in litres per day) } & Low production $(<8.58$ litres per day) & 47 & 21.36 \\
\hline & & Medium production ( 8.58 to 31.02 litres per day) & 128 & 58.18 \\
\hline & & High production (>31.02 litres per day) & 45 & 20.46 \\
\hline & & Average milk production (in litres) & \multicolumn{2}{|c|}{24.80 litres per day } \\
\hline \multirow{4}{*}{4} & \multirow{4}{*}{ Milk consumption (litres/day) } & Low (<1 litre/day) & 78 & 35.45 \\
\hline & & Medium (1-2 litres/day) & 112 & 50.91 \\
\hline & & High (>2 litres/day) & 30 & 13.64 \\
\hline & & Average milk consumption (litres/day) & \multicolumn{2}{|c|}{1.23 litres/day } \\
\hline \multirow{4}{*}{5} & \multirow{4}{*}{ Milk sale (litres/day) } & Low (<7.58 litre/day) & 38 & 17.27 \\
\hline & & Medium (7.58-39.42 litres/day) & 143 & 65.00 \\
\hline & & High (>39.42 litres/day) & 39 & 17.73 \\
\hline & & Average milk sale (litres/day) & \multicolumn{2}{|c|}{23.50 litres/day } \\
\hline \multirow[t]{4}{*}{6} & \multirow{4}{*}{ Annual income (in Rupees) } & Low (<Rs. 70, 000) & 68 & 30.91 \\
\hline & & Medium (Rs. 70,000- Rs. 1,90,000) & 107 & 48.64 \\
\hline & & High (> Rs. 1,90,000) & 45 & 20.45 \\
\hline & & Average annual income & \multicolumn{2}{|c|}{ Rs. $1,30,750$} \\
\hline
\end{tabular}

\section{Milk production}

Observations from Table 4.2 indicates that significant per cent $(58.18 \%)$ of the respondents had medium level of milk production followed by low $(21.36 \%)$ and high $(20.46 \%)$. The reason for medium level of milk production could be attributed to the medium livestock possession by the respondents with milk productivity of animals 4.96 litres/day. The results are in conformity to Porchezhiyan (2013) ${ }^{[10]}$.

\section{Milk consumption}

The depicted results from Table 4.2 revealed that fifty per cent $(50.91 \%)$ of respondents had medium milk consumption, followed by low $(35.45 \%)$ and high $(13.64 \%)$. The average milk consumption per family was 1.23 litres per day. The reason for medium milk consumption might be that majority of families were nuclear families with size of family less than five members.

\section{Milk sale}

It could be indicated from Table 4.2 that majority (65.00\%) of respondents had medium milk sale, followed by high $(17.73 \%)$ and low (17.27\%). This findings is directly related to the milk production where majority of the respondents belonged to medium milk production. The results are in 
agreement with the results of Meena (2012) ${ }^{[7]}$ who reported that majority of the dairy farmers were selling milk in between 4 to $41 \mathrm{~kg} /$ day in Karnal district.

\section{Annual income}

The data in Table 4.2 clearly indicates that, almost half $(48.64 \%)$ of the respondents belong to medium income category (Rs. 70,000 to Rs. 1,90,000), followed by low $(30.91 \%)$ and high $(20.45 \%)$. The average annual income of the respondents was Rs. 1,30,750. The reason might be due to increase in cost of milk production, cultivation and failure of crops which has resulted in youth to participate in non-farm activities in order to get sufficient income. Dairying was an important activity of the farm households and contribution of annual income through dairying was Rs. 82,000 which was 61.27 per cent of total annual income. The results are conformity to the results of Saroj et al., (2015) [12] and Laishram (2012) ${ }^{[5]}$ where majority of dairy farmers were under medium income group.

\section{Socio-psychological variables}

\section{Market behaviour}

A perusal of Table 4.3 indicates that, more than fifty per cent $(51.82 \%)$ of the respondents had medium level of market behaviour, followed by low $(35.45 \%)$ and small per cent $(12.73 \%)$ of respondents had high market behaviour.

Table 3: Distribution of respondents according to their market behaviour, $(n=220)$

\begin{tabular}{|c|c|c|}
\hline Market behavior & Frequency & Per cent \\
\hline Low (8-11) & 78 & 35.45 \\
\hline Medium (12-15) & 114 & 51.82 \\
\hline High (16-19) & 28 & 12.73 \\
\hline
\end{tabular}

\section{Participation in Extension Activities}

It could be seen from Table 4.4 that majority $(65.00 \%)$ of the respondents had low level of participation followed by medium $(30.45 \%)$ and high $(4.55 \%)$.
Table 4: Distribution of respondents according to their Participation in extension activities, $(\mathrm{n}=220)$

\begin{tabular}{|c|c|c|c|}
\hline S. No & Category & Frequency & Per cent \\
\hline 1. & Low $(8-10)$ & 143 & 65.00 \\
\hline 2. & Medium $(11-13)$ & 67 & 30.45 \\
\hline 3. & High $(14-16)$ & 10 & 4.55 \\
\hline
\end{tabular}

The reason might be low participation in extension activitieswas the cooperatives observed in the study were nonfunctional with respect to group activities. The results are in conformity to the results of Mohan and Reddy (2012) [8] where majority of respondents had low extension participation.

\section{Information seeking behaviour}

It was found from Table 4.5 that,more than fifty per cent $(50.91 \%)$ of respondents had medium information seeking behaviour followed by less than one-third of respondents $(32.27 \%)$ and notable per cent $(16.82 \%)$. The results are in conformity with the findings of Laishram (2012) [5] where majority of respondents had medium information seeking behaviour where in contrast with the findings of Vijay Kumar (2001) ${ }^{[15]}$, who reported that 41.66 per cent of entrepreneurs had low information seeking behaviour.

Table 5: Distribution of respondents according to their information seeking behaviour, $(n=220)$

\begin{tabular}{|c|c|c|c|}
\hline S.No & Category & Frequency & Per cent \\
\hline 1. & Low (9-12) & 71 & 32.27 \\
\hline 2. & Medium (13-16) & 112 & 50.91 \\
\hline 3. & High (17-20) & 37 & 16.82 \\
\hline
\end{tabular}

\section{Knowledge on improved dairy management practices}

A perusal from Table 4.6, reveals that considerable per cent $(44.55 \%)$ of respondents had overall medium level of knowledge on improved dairy farming, followed by high $(29.09 \%)$ and low $(26.36 \%)$. The results are in accordance with the findings of Patel et al., (2016) ${ }^{[9]}$.

Table 6: Distribution of respondents according to overall knowledge on improved dairy farming practices, $(\mathrm{n}=220)$

\begin{tabular}{|c|c|c|c|}
\hline Variable & Categories & Frequency & Per cent \\
\hline \multirow{3}{*}{ Knowledge on improved dairy farming practices } & Low $(20-23)$ & 58 & 26.36 \\
\cline { 2 - 4 } & Medium $(24-27)$ & 98 & 44.55 \\
\cline { 2 - 4 } & High $(28-32)$ & 64 & 29.09 \\
\hline & Total & 220 & 100 \\
\hline
\end{tabular}

Majority of respondents had knowledge about selection of good milch breeds, improved breeds, feeding colostrum to newly born calves, feed proportion, contagious diseases, and practices of clean milk production. Only few respondents had knowledge with respect to right time for artificial insemination, practices for newly born calves, right time for vaccination, records to be maintained. Education, high dairy farming experience, social participation and information seeking behaviour might have contributed towards knowledge towards these improved dairy farming practices. The results are in conformity to Laishram (2012) ${ }^{[5]}$ and Patel et al., (2016) ${ }^{[9]}$ where majority of respondents had knowledge.

\section{Conclusion}

It can be concluded from the study that majority of the respondents had high dairy farming experience, with low trainings, with high school education and hence there is need to design needs based course curriculum for youth in dairying order to update latest technologies and practices. Though majority of the respondents had medium milk production with medium annual income, in order to achieve high annual income low cost infrastructure must be developed in order to encourage processing of milk with proper training facilities. Majority of the respondents had social participation in 1-2 organizations but participation in extension activities is low, hence committed persons must be selected as leaders with definite roles and responsibilities among members in order to encourage youth participation in extension activities. Most of the respondents were procuring inputs individually hence sensitization needs to be created by extension agencies about importance of collective action. Most of respondents had medium information seeking behaviour hence there is need to encourage pluralistic extension services by extension agencies as it will enhance information availability among youth. 


\section{References}

1. Avadh S. Entrepreneurial behaviour among beneficiaries of Dairy Venture Capital Fund Scheme in Ahmednagar District of Maharastra. M.V.Sc. Thesis. National Dairy Research Institute, Karnal, Haryana, India 2011.

2. Gaikwad. Dairy Animal Productivity Enhancement Programme in Ahmednagar District of Maharastra: An Exploratory study. M.Sc. Thesis. National Dairy Research Institute, Karnal, Haryana, India 2010.

3. Government of India. Report of working group of adolescent and youth development. Department of Youth Affairs, Ministry of Youth Affairs and Sports for formulation of $12^{\text {th }}$ Five year plan (2012-2017). Ministry of Youth Affairs and Sports, New Delhi 2011b.

4. Gwary MM, Kwaghe PV, Ja'afar- Furo MR, Dennis A. Analysis of entrepreneurial agricultural activities of youths in Michika Local Government Area of Adamawa State, Nigeria. Journal of Development and Agricultural Economics 2011;3(3):91-97.

5. Laishram. Entrepreneurial behaviour on scientific dairy farming among youth of Manipur. M. Sc. Thesis. National Dairy Research Institute, Karnal, Haryana, India 2012

6. Mbah EN, Ezeano C, Odiaka EC. Analysis of rural youth's participation in family farming in Benue State, Nigeria: Implications for policy. Current Research in Agricultural Sciences 2016;3(3):46-56.

7. Meena K. Knowledge index for measuring knowledge and adopting scientific methods in treatment of reproductive problems of dairy animal. Journal of Agricultural Sciences 2012;4(10):81-88.

8. Mohan K, Reddy PRK. Profile characteristics of farmers under tankirrigation commands. Karnataka Journal of Agricultural Sciences 2012;25(3):359-362.

9. Patel NK, Ashwar BK, Modh VR, Khanushiya AF, Chaudhari JD, Parmar KN. Knowledge Level of Commercial Dairy Farmers About Scientific Dairy Farming Practices in Aravalli District of North Gujarat. Advances in Life Sciences 2016;5(13):5461-5463.

10. Porchezhiyan S. A study on Entrepreneurial profile of dairy farmers in the Northern Districts of Tamil Nadu. M. V Sc. Thesis. National Dairy Research Institute, Karnal, Haryana, India 2013.

11. Prosper JK, Nathaniel NT, Benson HM. Determinants of rural youth'sparticipation in agricultural activities. International Journal of Economics, Commerce and Management 2015;3:2348-2386.

12. Saroj K, Sethi N, Malik JS, Yogi V. Need assessment of women dairy farmers. Advances in Social Research 2015;1(1):35-42.

13. Swaminathan MS. Youth for agricultural transformation. Forum of free enterprise. Mumbai 2011.

14. Uddin ME, Rashid MU, Akanda MGR. Attitude of Coastal Rural Youth towards some selected modern Agricultural Technologies. Journal of Agriculture and Rural Development 2008;6(1):133-138.

15. Vijay Kumar K. Entrepreneurship behaviour of floriculture farmers in Ranga Reddy District of Andhra Pradesh. M.Sc. Thesis. Acharya N. G. Ranga Agricultural University, Hyderabad 2001.

16. World Bank. Development of next generation. World Bank Report (Report number-35999), Washington. DC 2007. 